
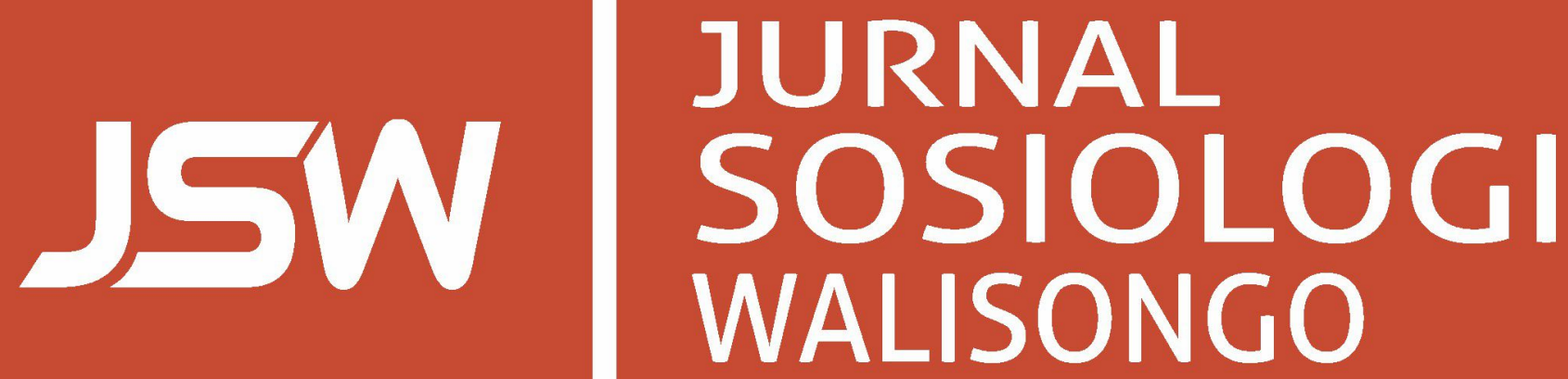

Studi Etnoekologi tentang Nelayan dan Jaring Cantrang

di Kabupaten Rembang

Hesti Rofika Sari, Nugroho Trisnu Brata

Perlawanan Visual Perempuan dalam Poster

Misbah Zulfa Elizabeth

Kearifan Budaya Lokal sebagai Benteng Munculnya Konflik Agama Muhammad Alfan Sidik

Ulama Pasca Sunan Gunung Jati: Jaringan Intelektual Islam Cirebon Abad ke-16 sampai dengan Abad ke-18

Didin Nurul Rosidin

Membangun Harmoni Sosial: Kajian Sosiologi Agama tentang Kearifan Lokal sebagai Modal Dasar Harmoni Sosial David Samiyono

Analisis Komparatif atas Hasil Tracer Study Program Studi Hubungan Internasional dan Administrasi Negara Muhyar Fanani, Akhriyadi Sofian, Kaisar Atmaja, Endang Supriadi

Melihat Indonesia dari Jendela Papua: Kebinekaan dalam Rajutan Budaya Melanesia Akhmad Kadir 

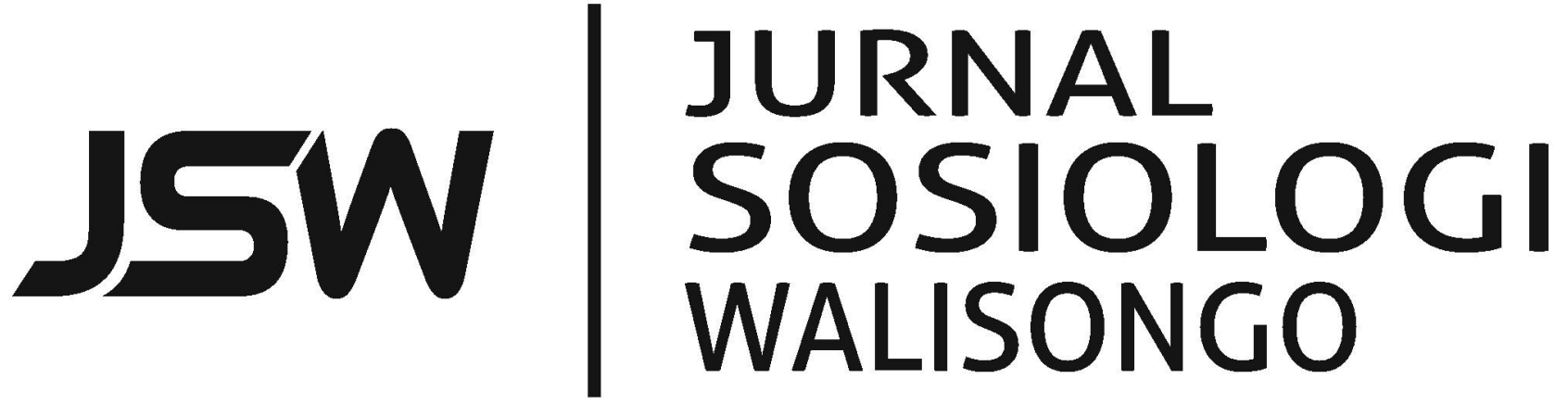

JSW: Jurnal Sosiologi Walisongo - ISSN 2503-3166 (print) ISSN 2503-3182 (online) is a critical, reflective, and transformative academic media that is published by Laboratorium Sosiologi, Fakultas IImu Sosial dan IImu Politik, Universitas Islam Negeri Walisongo Semarang, in the effort for developing the discipline of Sociology having the perspective of unity of sciences. Article is based on research in all division of sociology like sociology of religion, sociology of politic, sociology of law, sociology of development, urban/rural sociology, democracy, social ethic, anthropology, community development, social philosophy, gender, and social welfare.

\section{Editor in Chief}

Misbah Zulfa Elizabeth, Universitas Islam Negeri Walisongo, Semarang

\section{Expert Editor}

Abu Rokhmad, Universitas Islam Negeri Walisongo, Semarang

Muhyar Fanani, Universitas Islam Negeri Walisongo, Semarang

Thohir Yuli Kusmanto, Universitas Islam Negeri Walisongo, Semarang

\section{Editor}

Kaisar Atmaja, Universitas Islam Negeri Walisongo, Semarang

Akhriyadi Sofian, Universitas Islam Negeri Walisongo, Semarang

Nur Hasyim, Universitas Islam Negeri Walisongo, Semarang

\section{Layout Editor}

Helmi Suyanto, Universitas Islam Negeri Walisongo, Semarang

Ulul Azmi, Universitas Islam Negeri Walisongo, Semarang

\section{Publisher}

LABORATORIUM SOSIOLOGI

Fakultas IImu Sosial dan IImu Politik

Universitas Islam Negeri Walisongo

Semarang - Indonesia

\section{Address}

Gedung A - Fakultas IImu Sosial dan IImu Politik (FISIP)

Universitas Islam Negeri Walisongo, Semarang - Indonesia

Jl. Prof. Dr. HAMKA, Km. 2 Tambakaji Ngaliyan Semarang 50185

Phone +62.24 - 76435986

e-mail:jurnal.sosiologi@walisongo.ac.id 


\section{Table of Contents}

Studi Etnoekologi tentang Nelayan dan Jaring Cantrang di Kabupaten Rembang

Hesti Rofika Sari, Nugroho Trisnu Brata (Universitas Negeri

Semarang)

$135-146$

Perlawanan Visual Perempuan dalam Poster

Misbah Zulfa Elizabeth (Universitas Islam Negeri Walisongo,

Semarang)

$147-160$

Kearifan Budaya Lokal sebagai Benteng Munculnya

Konflik Agama

Muhammad Alfan Sidik (STAI Natuna)

$161-176$

Ulama Pasca Sunan Gunung Jati: Jaringan Intelektual Islam

Cirebon Abad ke-16 sampai dengan Abad ke-18

Didin Nurul Rosidin (Institut Agama Islam Negeri Syekh Nurjati,

Cirebon)

$177-194$

Membangun Harmoni Sosial: Kajian Sosiologi Agama tentang

Kearifan Lokal sebagai Modal Dasar Harmoni Sosial

David Samiyono (UKSW, Salatiga)

$195-206$

Analisis Komparatif atas Hasil Tracer Study Program Studi

Hubungan Internasional dan Administrasi Negara

Muhyar Fanani, Akhriyadi Sofian, Kaisar Atmaja, Endang Supriadi

(Universitas Islam Negeri Walisongo, Semarang)

$207-224$

Melihat Indonesia dari Jendela Papua: Kebinekaan dalam

Rajutan Budaya Melanesia

Akhmad Kadir (Universitas Cendrawasih, Jayapura)

$225-246$

Author Guidelines

JSW: Jurnal Sosiologi Walisongo - Vol 1, No 2 (2017) 



\title{
Ulama Pasca Sunan Gunung Jati: Jaringan Intelektual Islam Cirebon Abad ke-16 sampai dengan Abad ke-18
}

\author{
Didin Nurul Rosidin \\ Institut Agama Islam Negeri Syekh Nurjati, Cirebon \\ (e-mail: didinnurulrosidin@yahoo.co.id)
}

\begin{abstract}
This article related to the dynamic of islam intellectual network in Cirebon post Sunan Gunung Jati in the late of 16 century until early of 18 century. This era has been crucial because every dynamic of islam intellectual network happened after the death of Sunan Gunung Jati. Then the implication had headed to the existence of islamic education institution which is held in Keraton, one of the basis where islamic intellectual network in Cirebon, and also to the dominant intellectual discourse that evolved for two centuries. There are three stages of islam intellectual network progress in Indonesia which is related to middle east as a center and also main reference since 13 century untill 20 century. Firts, islamisasi (islamisation). This was when Islam for the first time spreaded by moslem's traders, travelers, and moslem scholars (ulama). This happened around 13 century. Second, neo-sufism. Neo sufism has occured for 3 centuries, since 16 centuries till 18 centuries. In this era some moslem scholars have had significant roles to disseminate knowledge and movement from middle east to Nusantara. And third, purification of islam. Some moslem scholars that have already finished their study and hajj became active to spread the ideas of purification of islam which developed in middle east.
\end{abstract}

Artikel ini membahas mengenai dinamika jaringan intelektual Islam di Cirebon paska Sunan Gunung Jati pada akhir abad ke-16 hingga awal abad ke-18. Era tersebut sangat krusial karena setiap dinamika jaringan intelektual Islam berlangsung setelah kematian Sunan Gunung Jati. Sehingga implikasinya mengarah pada eksistensi institusi pendidikan Islam yang ada di dalam Keraton, yang notabene merupakan salah satu basis dari jaringan intelektual Islam yang ada di Cirebon, pun merupakan wacana intelektual dominan yang berlangsung selama dua abad. Terdapat tiga tahap perkembangan jaringan intelektual Islam di Indonesia yang terkait dengan Timur Tengah yang merupakan pusat dan juga referensi utama sejak abad ke-13 hingga abad ke20. Pertama, islamisasi (islamisation). Tahapan ini merupakan era dimana untuk pertama kali Islam disebarkan oleh para pedagang muslim, penjelajah, dan cendekiawan muslim (ulama). Ini berlangsung sekitar abad ke-13. Kedua, neo-sufism. Neo sufisme telah berlangsung selama tiga 
abad, sejak abad ke-16 hingga abad ke-18. Dalam era ini sebagian cendekiawan muslim telah mempunyai banyak peran yang sangat signifikan untuk mendiseminasikan pengetahuan dan pergerakan dari Timur Tengah ke seluruh Nusantara. Ketiga, purifikasi Islam. Sebagian cendekiawan muslim telah menyelesaikan pendidikan dan ibadah haji mereka dan kemudian aktif menyebarkan ide-ide mengenai kemurnian Islam yang berkembang di Timur Tengah.

Keywords: moslem intellectual network; keraton; educational institute; scholarly tradition

\section{Pendahuluan}

Artikel ini terkait dengan dinamika jaringan intelektual Islam di Cirebon paska Sunan Gunung Jati pada akhir abad ke-16 hingga awal abad ke-18. Masa ini sangat krusial mengingat perubahan yang terjadi setelah meninggalnya sosok wali agung yang sangat dihormati di pulau Jawa, bahkan Nusantara, tersebut. Para pewaris tahta kerajaan Islam ini memiliki beban untuk meneruskan berbagai warisan agung yang ditinggalkannya, termasuk jaringan intelektual Islam yang terwadahi dalam beragam institusi pendidikan Islam di Keraton.Intervensi VOC yang kafir menambah beratnya beban sekaligus tantangan yang harus dihadapi.Pada saat yang sama, kekuasaan politik Islam di Cirebon justru terpecah ke beberapa Kerajaan kecil. Terlebih lagi bahwa Kompeni berhasil menancapkan pengaruhnya hingga mengakibatkan Keraton seperti kehilangan klaim utamanya sebagai pusat syiar sekaligus pendidikan Islam.Hal ini mendorong gerakan oposisi dari kalangan ulama Keraton yang pada akhirnya melahirkan jaringan intelektual Islam baru dimana pesantren sebagai locus utamanya. Berbagai perubahan inilah yang menjadi faktor dinamisnya perkembangan jaringan intelektual Islam di Cirebon (Azra 1998; Carey 2008).

Pembentukan jaringan intelektual Islam ini tidak lepas dari proses Islamisasi di Cirebon. Islamisasi di wilayah ini dilakukan oleh para muballigh seperti Syekh Hasanuddin, Syekh Nurjati, Pangeran Cakrabuana, Syekh Bayanullah dan Sunan Gunung Jati. Gerakan ini telah menjadikan wilayah ini tidak saja menjadi salah pusat kekuatan politik Islam yang sangat diperhitungkan melalui Kerajaan Islam Cirebon dan Banten, tetapi juga di kemudian hari menjadikannya sebagai salah satu kiblat keilmuan Islam (puser bumi) di pulau Jawa khususnya dan Nusantara pada umumnya. Prestasi yang kedua tersebut membawa Cirebon menjadi salah satu sumbu penting dalam jaringan intelektual Islam di Nusantara (Abdurrahman 1996).

Hal lain yang perlu dicatat terkait dengan jaringan intelektual Islam ini ialah 
bahwa para muballigh awal tersebut tercatat sebagai alumni Timur Tengah, terutama Mekah dan Madinah. Mereka bisa dikatakan sebagai sanad utama transmisi keilmuan Islam dari Timur Tengah ke Cirebon. Transmisi ini diperkuat oleh pendirian lembaga pendidikan Islam seperti Pengguran Amparan Jati, Pejalagrahan, Dalem Agung Pakungwati, Mesjid Astana dan Mesjid Agung Sang Cipta Rasa. Melalui lembaga-lembaga pendidikan Islam inilah, jaringan intelektual Islam terbentuk di Kerajaan Islam Cirebon yang diproklamasikan kemerdekaannya dari Kerajaan Hindu Pajajaran pada akhir abad ke-15 (Hardjasaputra dan Haris Tawalinudin 2011).

Pendirian Kerajaan Islam berikut lembaga-lembaga pendidikannya menjadikan Keraton sebagai titik pusat jaringan intelektual Islam di Cirebon. Transmisi keilmuan menjadi identik dengan transmisi politik dan keagamaan. Tidak heran jika sosok pemimpin Kerajaan Islam ini tidak saja mewakili sosok Raja yang berkuasa secara politik tetapi juga sosok wali yang ahli agama dan sumber otoritas keilmuan Islam. Patatah-petitih Sunan Gunung Jati berfungsi tidak saja sebagai kebijakan politik tetapi juga ajaran agama yang paling otoritatif sekaligus otentik. Kerangka hubungan politik, agama dan ilmu seperti ini nampaknya telah menjadi standar bagi cara pandang kaum Muslim Cirebon pada masa awal terhadap fungsi raja (sultan) dan keratonnya.
Jika Sunan Gunung Jati nampaknya begitu sempurna untuk memerankan fungsi sebagai Raja sekaligus wali, hal yang tentunya tidak mudah untuk dilakukan oleh para penerusnya. Selain faktor kualitas personal dari masing-masing penerusnya, perubahan situasi baik politik maupun lainnya berikut tantangannya tentunya juga turut berperan dalam perubahan yang terjadi di Cirebon setelah meninggalnya sang wali agung tersebut. Cirebon sebagai simbol sekaligus pusat politik, agama dan transmisi keilmuan Islam relatif bertahan paling tidak ketika Cirebon di bawah kepemimpinan Panembahan Ratu (b. 1570-1649) yang digambarkan oleh sumber-sumber lokal sebagai seorang pertapa (Cerbon 1978; Atja 1986).

Namun situasi tersebut berubah setelah meninggalnya Panembahan Ratu. Panembahan Girilaya (b. 1949-1662) gagal menampilkan diri sebagai sosok ulama sekaligus raja sebagaimana para pandahulunya. Kegagalan ini berdampak pada menurunnya wibawa Kerajaan Islam di mata para penguasa Kerajaan Islam di pulau Jawa. Hal ini terlihat pada gagalnya ia membendung intervensi politik Mataram yang berakhir dengan tragedi meninggalnya Panembahan Girilaya dengan status sebagai pesakitan. Krisis politik akibat kekosongan penguasa menyusul meninggalnya penguasa keempat di dalam tahanan di ibukota Mataram dipersulit oleh intervensi kekuatan politik Islam lainnya yaitu Ke- 
rajaan Islam Banten. Beragam intervensi politik ini berujung pada terpecahnya Kerajaan Islam Cirebon ke tiga pusat kekuasaan kecil (Kasepuhan, Kanoman dan Kepanembahan). Krisis politik ini ternyata terus berlanjut, bahkan bisa dikatakan semakin akut, ketika VOC secara langsung terlibat dalam urusan politik internal Cirebon pada akhir abad ke-17 hingga abad-abad berikutnya ketika Cirebon berada dalam penjajahan Pemerintah Kolonial Belanda.

Krisis politik ini tentunya berpengaruh terhadap kedudukan Cirebon sebagai pusat agama dan keilmuan Islam, paling tidak untuk kaum Muslim lokal. Pada awalnya, beragam intervensi politik eksternal tersebut belum banyak berpengaruh terhadap kedudukan dan status Cirebon tersebut.Namun situasi ini berubah ketika VOC yang khawatir terhadap pengaruh para ulama terhadap eksistensi dan kepentingan dagang mereka memaksa pihak Keraton untuk melepaskan salah satu fungsi utamanya sebagai pusat pendidikan dan belajar Islam pada awal abad ke-18. Hal itu ditandai oleh ditutupnya Dalem Agung Pakungwati sebagai pusat pendidikan Islam di dalam Keraton. Selain itu, lembaga pendidikan Islam lainnya seperti Mesjid Agung Sang Cipta Rasa dan Mesjid Astana berada dalam pengawasan ketat pihak VOC. Akibatnya, pusat pendidikan Islam berpindah ke luar Keraton dan menjadi titik awal terbentuk- nya jaringan intelektual Islam baru dengan pesantren sebagai basisnya dan berpusat di wilayah pedesaan. Kiai Muqoyyim (Mbah Muqoyyim) merupakan pionir dalam pembentukan jaringan intelektual Islam berbasis pesantren ini di wilayah Cirebon. Pada masa selanjutnya, pesantren berikut para kiai dan alumninya menjadi pelaku utama jaringan intelektual Islam di Cirebon, meskipun tidak berarti bahwa peran Keraton sama sekali hilang sebagaimana terlihat dari lahirnya Pengguran Kaprabon dan pengguran lainnya (Hadi 2014).

Tentunya menarik jika kita menghubungkan jaringan intelektual dan tradisi keilmuan Islam Cirebon yang cenderung menurun pada abad ke-17 dan abad ke-18 dengan perkembangan jaringan intelektual dan tradisi keilmuan Islam di Nusantara yang justru sangat pesat pada masa itu. Terkait dengan topik tersebut di atas dalam konteks Nusantara telah banyak diulas oleh banyak sarjana terutama Azyumardi Azra (1998), Abdurrahman Mas'ud (2006), Michael Laffan, Jajat Burhanudin (2007), Oman Fathurrahman dan lain-lain. Lebih menantang lagi bahwa para sarjana pengkaji jaringan intelektual Islam Nusantara tersebut nyatanya tidak banyak menyebut apalagi membahas kiprah penting para ulama Cirebon pada perkembangan jaringan intelektual Islam Nusantara pada akhir abad ke-16 sampai pertengahan abad ke-18. 
Dari uraian di atas, artikel ini akan bertumpu pada beberapa masalah yang dirumuskan sebagai berikut: Bagaimana pola transmisi keilmuan sebagai bagian dari pembentukan jaringan intelektual Islam di Cirebon paska Sunan Gunung Jati (abad ke-16 sampai abad ke-18)? Siapa sajakah para ulama yang menjadi tokoh utama dalam jaringan intelektual Islam Cirebon pada kurun waktu tersebut? Apa sajakah wacana atau pemikiran yang berkembang dan atau dikembangkan oleh para ulama dan melalui jaringan intelektual Islam tersebut?

Dengan tiga pertanyaan tersebut, artikel ini akan mampu membantu kita untuk mengetahui pola transmisi keilmuan sebagai bagian dari pembentukan jaringan intelektual Islam di Cirebon paska Sunan Gunung Jati (abad ke-16 sampai abad ke18), para tokoh utama jaringan ulama Cirebon pada kurun waktu tersebut, dan wacana-wacana keilmuan yang berkembang dan atau dikembangkan oleh dan melalui jaringan ulama tersebut pada kurun waktu tersebut.

\section{Jaringan Intelektual dalam Tradisi Keilmuan Islam}

Studi tentang perkembangan tradisi keilmuan di Cirebon paska Sunan Gunung Jati harus dilihat dengan kacamata sejarah intelektual yang menekankan aspek dinamika perkembangan tradisi itu dari satu masa ke masa.Karenanya, tidak tepat jika pendekatan yang dikembangkan itu seperti studi pemikiran tokoh tertentu dan karya pemikiran tertentu yang menekankan pada peran menonjol sosok-sosok tertentu atau teks-teks atau pemikiran tertentu. Selain itu pendekatan yang terakhir juga mengesankan bahwa pemikiranpemikiran individu tersebut cenderung statis dan stabil (Burhanuddin 2007: 6). Sebaliknya, pendekatan sejarah intelektual justru menekankan aspek dinamis dari perkembangan tradisi keilmuan yang dikembangkan oleh para ulama dari satu masa ke masa lain atau dinamika pemikiran antara beragam individu.

Pada awalnya, pendekatan sejarah intelektual ini sebagai kritik terhadap pendekatan yang dikembangkan Annales Perancis yang melihat teks sebagai sesuatu yang hanya dijelaskan. Sebaliknya, pendekatan sejarah intelekual yang dikembangkan oleh beberapa ahli sejarah seperti J. G. A. Pocock, Hayden White, Dominic Lacapra dan Quentin Skinner justru melihat teks sebagai sebuah realitas yang otonom yang bisa berperan untuk menjelaskan atau bahkan menciptakan realitas sejarah (Burhanuddin 2007: 6). Dengan kata lain, teks sebagai produk sebuah ekspresi bahasa dari berbagai macam ide dan pemikiran yang dikembangkan oleh para pelaku sejarah memiliki posisi yang sama sebagai sebuah realitas yang memiliki hubungan yang sangat erat dengan realitas politik, ekonomi dan sosial masyarakat yang menjadi 
kajian sejarah. Artinya, teks memiliki peran penting dalam proses penjelasan sejarah. Melalui teks pula, kita bisa melihat sejarah sebagai sesuatu yang dinamis.

Dengan pengertian tentang pendekatan sejarah intelektual di atas, pemikiran yang dikembangkan oleh para ulama sebagai sebuah teks akan berperan dalam membantu kita memahami sejarah dimana, kapan para ulama itu hidup dan berperan dan bagaimana hubungannya dengan realitas politik, sosial dan ekonomi saat itu. Implikasi lebih lanjut dari pendekatan ini adalah bahwa perkembangan pemikiran ulama berikut jaringannya dari masa ke masa sangat ditekankan dan selalu pula dikaitkan dengan situasi sosial, budaya, politik dan bahkan agama pada masanya. Dengan kerangka tersebut, para ulama akan dilihat sebagai sosok-sosok yang kreatif yang mampu merespon beragam tantangan yang muncul di hadapannya dan menariknya seringkali tidak terkait langsung dengan isyu agama dengan tetap berpedoman pada warisan intelektual, nilai dan norma yang pernah dikembangkan oleh ulama-ulama sebelumnya.

Kerangka di atas otomatis membahwa kita untuk memahami tradisi keilmuan di sini bukan sebagai sesuatu yang merupakan upaya untuk melanggengkan masa lalu. Akan tetapi, tradisi keilmuan di sini adalah sebagaimana dijelaskan oleh Jajat Burhanudin sebagai "suatu pola paradigma budaya dimana para ulama mengkonseptualisasikan realitas yang ada dihadapi berikut nilai dan normanya yang dengan itu semua para ulama mendefinisikan Islam sebagai rujukan untuk kaum Muslim". Dalam memberikan pengertian tentang tradisi seperti itu, Jajat Burhanudin merujuk pada pandangan Edward Shils yang melihat tradisi sebagai "suatu proses menciptakan dan mereproduksi apa yang diyakini telah ada dan telah dilaksanakan pada masa lalu". Dengan dasar itu, tradisi harus dilihat sebagai "sebuah aktivitas mental atau salah satu model berfikir" (Burhanuddin 2007: 6). Dalam kerangka tersebut, para ulama berupaya mengkontruksi ulang, modifykasi, beragumentasi dan menemukan kenyataan masa lalu yang dihadapi dengan cara pandang kontemporer pada masa dimana ulama tersebut hidup dan berperan.

Sementara itu dari sisi jaringan intelektual yang berfungsi untuk meneruskan tradisi kelimuan dari satu masa ke masa berikutnya, pola penyebaran keilmuan Islam di pulau Jawa khususnya dan Nusantara pada umumnya tidak lepas dari sistem keilmuan Islam klasik yang menekankan hubungan yang solid antara guru dengan murid seperti sistem sanad hadist dan atau mengikuti pola hubungan murshid dan murid dalan tradisi tasawuf yang dikenal dengan istilah tariqah tarsilah. Pola ini menggambarkan hubungan "vertikal" antara guru dengan murid 
dalam kerangka pengembangan jaringan intelektual Islam. Sementara bukti akan adanya hubungan tersebut melalui proses sertifikasi atau pemberian lisensi yang dikenal dengan istilah ijazah atau juga penggunaan karya-karya gurunya sebagai acuan dalam proses pengajaran untuk muridmuridnya (Azra 2006: 184-5).

Selain jalur vertikal, pengembangan jaringan intelektual Islam juga dilakukan melalui jalur "horizontal" seperti melalui pernikahan maupun rekruitmen yang khusus dilakukan oleh seorang atau kelompok masyarakat yang menghendaki. Pola ini bahkan terus berlanjut pada saat pesantren mulai berkembang. Dalam konteks itu, metode terakhir ini biasanya dilakukan dengan cara pihak pengundang menyediakan tempat dan segala kebutuhan guna pendirian pesantren, sementara santri yang baru lulus dan beranjak menjadi "Kiai anom" direkrut untuk memimpin lembaga pendidikan tradisional yang baru saja didirikan.

Sebenarnya telah banyak penelitian dan kajian tentang Islam di Cirebon, beberapa di antaranya seperti Sharon Joy Shiddique (1977), Abdul Goffar Muhaimin (1995), Opan Sopari (2010), Machrus elMawa (2010a dan b) Zaenal Masduqi (2012), Didin Nurul Rosidin (2013) dan lain-lain. Meskipun demikian, para sarjana tersebut di atas tidak banyak yang membahas tentang sejarah dan jaringan intelektual terutama pada abad ke-16 sampai dengan abad ke-18 sebagai akar lahirnya jaringan pesantren di Cirebon. Selain itu, masa ini bisa dipandang penting dan strategis, jika dilihat sebagai jembatan penguhung antara masa Sunan Gunung Jati dan masa berkembangnya jaringan intelektual Islam melalui pesantren. Artinya, rentang waktu penelitian ini berujung pada munculnya pesantren Buntet pada pertengahan abad ke-17. Di sinilah pentingnya artikel yang lebih serius tentang jaringan intelektual dan tradisi keilmuan Islam yang berkembang paska Sunan Gunung Jati. Kajian model ini juga guna untuk menempatkan secara tepat sekaligus juga memahami karakter pemikiran Islam di kalangan ulama Cirebon pada masa itu. Pastinya, karakter pemikiran Islam yang eksklusif akan memberi pengaruh pada perkembangan tradisi keilmuan pada masa selanjutnya, yaitu terutama pada saat Cirebon secara langsung berada di bawah pengaruh kolonialisme.

\section{Jaringan Intelektual Islam Nusantara}

Jika merujuk pada kajian para sarjana tentang perkembangan jaringan intelektual Islam Nusantara yang dikaitkan dengan Timur Tengah sebagai pusat sekaligus sumber rujukan sejak abad ke-13 hingga awal abad ke-20, terdapat paling tidak tiga episode perkembangan jaringan intelektual Islam antara kedua wilayah ini. Episode Islamisasi, episode diseminasi ide yang oleh Azra disebut neo-sufisme (Azra 
1998: 109-110) dan episode yang ketiga adalah ketika kaum Muslim Nusantara yang sadar akan belenggu pejajahan dan perlunya akan pembaharuan sikap dan prilaku keagamaan sebagai salah landasan kokoh bagi perlawanan terhadap kaum penjajah. Melalui tiga episode inilah, kaum Muslim Indonesia mengalami pasang surut pentingnya jaringan intelektual Islam antara Nusantara dengan Timur Tengah (Rosidin 2007: 6).

Episode pertama bisa dikatakan sebagai cikal bakal terciptanya jaringan intelektual Islam tersebut ketika kaum Muslim baik sebagai pedagang, pelancong hingga para ulama dari wilayah lain di dunia Islam, khususnya Timur Tengah, datang ke wilayah Nusantara dan mengenalkan ajaran Islam. Inilah episode yang sering disebut sebagai awal gerakan Islamisasi Nusantara. Orang-orang seperti Syekh Hasanuddin (Syekh Quro) di Karawang, Syekh Nurjati di Pasambangan, Maulana Malik Ibrahim di Gresik Jawa Timur dan lain-lain adalah para pionir yang berperan menghubungkan antara Nusantara yang masih didominasi oleh Hindu dan Budha dengan Timur Tengah dalam konteks penciptaan identitas agama baru yang bernama Islam. Terlihat jelas bahwa para ulama "asing alias baru" bisa dikatakan sebagai aktor utama pembentukan jaringan inteletual Islam paling awal antara Nusantara dengan Timur Tengah, bahkan mungkin dengan belahan dunia Islam lainnya seperti India dan Persia, termasuk juga Cina (Reid 2011; Wade 2012; Wade \&
Sun 2010). Dengan kata lain, Islamisasi merupakan titik awal terbangunnya jaringan intelektual Islam antara Nusantara dengan Timur Tengah.

Episode kedua terjadi kurang lebih selama tiga abad (abad ke-16 s.d 18). Masa ini bisa dikatakan sebagai masa meningkatnya hubungan secara politik dan intelektual antara Muslim Nusantara dengan mereka di Timur Tengah, terutama wilayah Hijaz dimana kota suci Mekkah dan Madinah plus Mesjidil Haram berikut Ka'bah dan Mesjid Nabawi. Pada episode kedua ini, para penguasa Muslim Nusantara seperti Mataram dan Banten menjadikan penguasa (syarif) Mekkah sebagai rujukan untuk melegitimasi kekuasaan mereka atas kaum Muslim di wilayahnya.

Pada saat yang sama, para ulama Nusantara juga mulai bisa memainkan peran yang cukup aktif untuk mentransmisikan ide dan gerakan Islam dari Timur Tengah ke Nusantara. Dalam prosesnya, para ulama, paling tidak calon ulama, Nusantara seperti Syekh Nuruddin ArRaniri, Abdul Rauf al-Singkili, Syekh Muhammad Yusuf al-Maqasari yang nantinya dikenal sebagai kelompok Jawiyyin pergi ke dua pusat peradaban utama Islam di wilayah Hijaz, Mekkah dan Madinah, untuk belajar kepada para ulama mashur yang telah berkembang di sana. Ilmu pengetahuan dan pengalaman yang mereka peroleh selama studi kemudian secara intensif bahkan massif disebarkan 
kepada kaum Muslim pribumi melalui murid-muridnya seperti Syekh Burhanuddin Ulakan, Syekh Abdul Muhyi dan Tengku Dawud al-Jawi al-Fansuri (Fathurrohman 2003: 42) dan atau menjadi sumber inspirasi bagi lahirnya perubahan kaum Muslim di Nusantara.

Episode yang ketiga adalah ketika para alumni haji Nusantara baik setelah belajar agama atau hanya melaksanakan rukun islam yang kelima mulai aktif menyebarkan pemikiran-pemikiran pembaharuan Islam yang berkembang di Timur Tengah. Secara umum, pemikiran-pemikiran Islam yang baru dikembangkan ini bertujuan untuk memurnikan ajaran Islam baik dari tradisi-tradisi lokal maupun dari pengaruh tasawuf. Pada awal abad ke-19 Tiga orang alumni Mekkah asal Sumatra Barat, Haji Miskin, Haji Abdurrahman dan Haji Sumanik yang banyak dipengaruhi oleh pemikiran Muhammad bin Abdul Wahhab di Mekkah (1703-1792) berkeyakinan Islam harus bersih dari pola agama sinkretis karena bercampur dengan tradisi lokal dan praktek-praktek sufisme (Fathurrohman 2003: 62-65).

Gerakan pembaharuan semakin massif pada akhir abad ke-19 dan awal abad ke 20. Tokoh seperti Syekh Akmad Khatib di Mekkah melalui murid-muridnya, Haji Abdul Karim, Syekh Jamil Jambek dan H, abdullah Ahmad di Minagkabau dan Ahmad Dahlan, H. Mas Abdurrahman dan A. Hassan di Jawa mengkampanyekan perlunya pernurnian ajaran Islam dan pentingnya ijtihad. Para alumni haji ini lebih menekankan aspek aktifisme dalam beragama dengan tujuan untuk melakukan perlawanan terhadap penjajahan. Sementara itu, dari sisi rujukan jaringan intelektual, para pembaharu Islam Nusantara tidak saja mengambil inspirasi dari wilayah Hijaz sebagaimana telah berlangsung selama episode kedua di atas, tetapi telah menjadikan ulama-ulama Mesir sebagai rujukan seperti Jamaluddin Al-Afghani dan Muhammad Abduh (lihat Jamal 1998: 1-45). Bisa dikatakan bahwa menjelang abad ke-20, kaum Muslim Nusantara pada umumnya dan Hindia Belanda pada khususnya menyaksikan beragam kontestasi pemikiran Islam yang dicoba dikampanyekan oleh para ulama, terutama alumni Timur Tengah.

Singkatnya, Islamisasi telah menjadi fondasi bagi dibangunnya jaringan intelektual Islam antara Nusantara sebagai wilayah pinggiran dengan Timur Tengah sebagai poros utama peradaban Islam. Menguatnya kedudukan Islam paska Islamisasi baik secara politik, ekonomi dan sosiologis telah semakin memperkuat jaringan intelektual Islam. Mekkah pada masa kejayaan politik Islam di Nusantara tidak saja berfungsi sebagai pencarian ilmu bagi para ulama dan pelajar Islam yang dengan itu para ulama menjadikannya sebagai rujukan standar pemahaman dan praketk keislaman yang 
otentik, tetapi juga sebagai legitimasi spiritual atas kekuasaan politik. Luluh lantaknya politik Islam akibat kolonialisme berdampak tidak saja pada polarisasi ulama di Nusantara tetapi juga pandangan tentang posisi kota suci Muslim. Para ulama pesantren tampil sebagai kelompok aktor utama penguatan sekaligus perluasan jaringan intelektual. Melalui mereka lah karya-karya ulama baik Jawi maupun nonJawi tersebar luas di Nusantara sekaligus memberikan akses bagi para santri di pesantren khususnya dan kaum Muslim umumnya terhadap pemikiran-pemikiran Islam, termasuk fatwa-fatwanya. Jaringan intelektual Islam inilah, kaum Muslim di Nusantara mengalami transformasi yang luar biasa pada akhir abad ke-19 dan awal abad ke-20.

\section{Islam Keraton Cirebon}

Berbicara tentang perkembangan Islam di Cirebon secara otomatis harus menyinggung "Islam Keraton". Hal itu tidak lepas dari fakta bahwa meski Islam pada awalnya tidak dikenalkan oleh para penguasa lokal, Islam di Cirebon pada masa selanjutnya identik dengan Keraton. Sosok Pangeran Cakrabuana dan Sunan Gunung Jati tidak saja merepresentasikan sebagai penguasa secara politik tetapi juga sebagai sosok penyebar Islam (muballigh). Artinya, Islam di Cirebon adalah Islam Keraton.

Pangeran Cakrabuana tercatat sebagai pendiri pertama Islam politik di Cirebon.
Dengan dukungan dan bimbingan secara penuh dari gurunya, Syekh Nurjati, dan mertuanya, Ki Gedheng Alang-alang, Pangeran Cakrabuana berhasil mentransformasikan wilayah yang "relatif tidak bertuan" yang bernama Kebon Pesisir menjadi wilayah yang maju. Kemajuan wilayah ini telah menarik para pelancong plus pedagang dari berbagai belahan dunia baik di Nusantara maupun mancanegara untuk datang, bahkan menetap di wilayah baru ini.tidak heran jija secara demografis, penduduk yang tinggal di wilayah ini pada masa itu telah heterogen secara etnis, budaya dan bahasa ataupun agama. Sebagai seorang penguasa Muslim yang taat, Pangeran Cakrabuana tidak ketinggalan juga membangun pusat syiar sekaligus pendidikan Islam yang nantinya dikenal dengan namaTajug Pejalagrahan. Dari tempat inilah, Islam berkembang dan menyebar ke wilayah lain di sekitar Cirebon.

Langkah yang lebih masif lagi dilakukan oleh penerus Pangeran Cakrabuana yang bernama Syarif Hidayatullah atau lebih dikenal dengan nama Sunan Gunung Jati, salah seorang dari Sembilan Wali (Walisongo) yang paling dihormati umat Islam di pulau Jawa. Di bawah kepemimpinannya, Islam menyebar di pulau Jawa bagian barat mulai Cirebon hingga Banten. Pada saat yang sama, ia juga berhasil mendirikan dua kerajaan Islam sekaligus di wilayah ini yaitu Cirebon (1485) dan Banten (1527) yang akan mendominasi 
percaturan, bahkan identitas politik Islam di wilayah ini hingga kini.

Gerakan Islamisasi Sunan Gunung Jati diperkuat oleh berbagai kebijakan yang dikeluarkannya. Tidak lama setelah diproklamasikan sebagai penguasa baru, ia mendeklarasikan kemerdekaan dari Kerajaan Hindu Pajajaran. Langkah-langkah berikutnya adalah pembangunan pusat pendidikan Islam Keraton di Dalem Agung Pakungwati, pembangunan Mesjid Agung Sang Cipta Rasa, dan penerapan beberapa aspek utma dalam hukum Islam, Islamisasi budaya dan tradisi lokal Cirebon dan lainlain. Massifnya Islamisasi ini menjadikan Cirebon sebagai salah satu kiblat utama kebudayaan dan peradaban Islam sekaligus menjadi referensi bagi kaum Muslim di Nusantara.

Posisi strategis Keraton sebagai pusat kekuasaan politik dan agama ini relatif mampu dipertahankan oleh para penguasa penerus Sunan Gunung Jati, terutama pada masa Fatahillah (b. 15681570), Panembahan Ratu (b. 1570-1649) dan Panembahan Girilaya (1649-1662). Meskipun demikian, sejak awal perlu digarisbawahi bahwa kecenderungannya terus merosot pamornya karena berbagai faktor yang mengitarinya sebagaimana telah dijelaskan secara ringkas pada bagi pendahuluan di atas.

Situasi benar-benar berubah ketika Kerajaan Islam Cirebon mengalami krisis politik menjelang dan setelah meninggal- nya Panembahan Girilaya akibat intervensi Kerajaan Islam Mataram. Ketika Kerajaan Islam Banten yang sedang bersaing dengan Mataram untuk perebutan pengaruh politik di pulau Jawa juga ikut melakukan intervensi politik, situasi politik di Cirebon semakin memburuk. Kerajaan Islam Cirebon terpecah kepada tiga pusat kekuasaan kecil (Kasepuhan, Kanoman dan Kapanembahan) pada akhir abad ke-17, sebelum pada awal ke-18 bertambah dengan lahirnya Kacirebonan. Kondisi politik yang terpecah ini menjadikan Cirebon pada akhir abad ke-17 dengan mudah dikuasai oleh VOC yang secara perlahan tapi pasti menghegemoni politik Cirebon. Para sultan, panembahan dan pangeran seperti tidak berdaya menghadapi tekanan dan infiltrasi massif VOC. Sebaliknya, mereka justru semakin ketergantungan pada "kebaikan dan Bantuan" VOC yang sebenarnya lebih berkonsentrasi pada untuk memastikan akan jaminan keamanan kepentingan ekonomi mereka sebagai sebuah perusahaan dagang asing.

Gonjang-ganjing politik pada akhir abad ke-17 dan selama abad ke-18 ini secara otomatis berakibat pada merosotnya, jika tidak boleh dikatakan hilangnya, kedudukan Keraton sebagai pusat politik dan agama sekaligus simbol nilai, keagungan dan identitas tradisional. Inilah yang kemudian menorong lahirnya gerakangerakan perlawanan baik secara simbolis maupun fisik. Para tokoh opisisi seperti Pangeran Kusumajaya, Ki Bagus Rangin 
hingga Kiai Muqoyyim tampil untuk memimpin perlawanan. Mereka bergerak keluar Keraton dan membangun basisbasis perlawanan di wilayah pedesaan yang jauh dari pusat kekuasaan yang berada di perkotaan.

Dari gambaran tersebut di atas, terlihat jelas bahwa intervensi berbagai kekuatan luar mulai dari Mataram, Banten dan Kompeni Belanda membawa implikasi yang luar biasa. Keraton Cirebon yang memang sejak awal tidak menampilkan diri sebagai institusi politik Kerajaan an sich tetapi juga sebagai pusat dakwah Islam kehilangan kharismanya. Sebagai reaksi akan runtuhnya kharisma Keraton, beberapa ulama melakukan perlawanan baik secara langsung seperti yang dilakukan oleh Pangeran Kusumajaya maupun secara tidak langsung seperti dengan mendirikan pesantren di luar wilayah Keraton sebagaimana yang dilakukan oleh Kiai Muqoyyim.

\section{Jaringan Intelektual Islam Cirebon}

Pembentukan jaringan intelektual Islam serta pola transmisi keilmuan Islam di Cirebon sangat terkait dengan perkembangan lembaga pendidikan Islam. Terlebih lagi jika dihubungkan dengan klaim yang banyak dicatat dalam naskahnaskah lokal bahwa Cirebon merupakan salah satu dari tiga puser bumi ilmu-ilmu Islam di pulau Jawa selain Demak dan Ampel Denta, Surabaya. Tidak heran jika Cirebon menjadi salah satu kiblat sekaligus rujukan ilmu pengetahuan Islam di pulau Jawa (Rido 2014: 45).1

Dalam konteks kelembagaan pendidikan Islam di Cirebon, Muhaimin membaginya ke dalam tiga episode (Muhaimin 1995: 207). Pertama, pendidikan Islam yang berada dan dikelola oleh masyarakat. Episode ini terjadi pada masa awal Islamisasi yaitu saat Syekh Nurjati mendirikan lembaga pendidikan Islam yang sering disebut dalam naskah-naskah lokal sebagai pengguran, meskipun terkadang juga disebut pesantren.

Kemudian terjadi transformasi kelembagaan pendidikan ketika Pangeran Cakrabuana yang menjadi penguasa Cirebon mendirikan tajug sebagai lembaga pendidikan Islam dan menjadi bagian dari struktur kekuasaan. Masuknya lembaga pendidikan ke dalam lingkungan kekuasaan semakin dominan tatkala Syarif Hidayatullah (Sunan Gunung Jati) menjadi raja sekaligus wali pada kerajaan Islam. Selain mempertahankan tajug Pejalagrahan, ia mendirikan lembaga pendidikan Islam baru seperti Pengguran Dalem

\footnotetext{
${ }^{1}$ Dalam sumber sejarah lokal yang berjudul Pustaka Rajya-rajya I Bhumi Nusantara sebagaimana yang dikutip oleh Rosidi Rido dinyatakan bahwa dalam konteks Islamisasi pulau Jawa, Cirebon merupakan salah satu dari tiga puser bumi selain Demak di Jawa Tengah dan Ampel Denta di Jawa Timur.Cirebon menjadi puser bumi di Jawa Barat. Secara rinci dalam naskah tersebut dinyatakan, "Ing Jawa dwipa hana telung siku puserbumi yatiku/Jawa kulwon yata Carbon/ Jawa mudhiya yata Demak/ Jawa wetan yatiku/ Ngampel denta neher giri/ ring nguni Geresik/.
} 
Agung Pakungwati dan Mesjid Agung Sang Cipta Rasa. Selain itu, Mesjid Astana yang menjadi pusat pendidikan Islam yang dibangun oleh Syekh Nurjati dan berada di Amparan Jati dimasukan menjadi bagian dari Kerajaan. Inilah periode kedua dimana lembaga pendidikan Islam menjadi bagian dari Keraton.

Khusus terkait dengan peran dan fungsi lembaga pendidikan Islam (Dalem Agung Pakungwati dan Mesjid Agung Sang Cipta Rasa) di Keraton, Sunan Gunung Jati menjadikannya sebagai "kawah candradimuka" bagi calon-calon pemimpin pemerintahan kerajaan Islam Cirebon dan kader-kader intelektual Islam yang akan Islam ke berbagai wilayah di pulau Jawa bagian barat khususnya dan Nusantara pada umumnya. Di sinilah Panembahan Ratu, Panembahan Girilaya, bahkan Sultan Agung Mataram pernah mengenyam pendidikan Islam pada masa mudanya. Fungsi dan kedudukan tersebut menjadikan lembaga-lembaga pendidikan Islam tersebut sebagai "mekkah"-nya bagi kaum Muslim di Cirebon khususnya. Petatahpetitih Sunan Gunung Jati menjadi bahan ajar utama sekaligus wacana yang paling dominan. Para ulama yang telibat pada lembaga-lembaga tersebut berperan sebagai guru, mufti bahkan qadi bagi pelaksanaan tata kehidupan keagamaan di Kerajaan Islam Cirebon. Begitu pentingnya posisi lembaga-lembaga pendidikan tersebut telah mendorong para pelajar Muslim di Cirebon untuk mencukupkan diri memperdalam agama di lembagalembaga tersebut. Sanad keilmuan hanya terpusat pada silsilah guru yang ada di lembaga pendidikan itu.Inilah yang menjadi cikal bakal lahirnya jaringan intelektual Islam lokal yang dalam banyak hal seperti terlepas dari jaringan intelektual Islam Nusantara bahkan global yang semakin berkembang pada abad ke-17 dan ke-18 (Effendi 1994).

Status Dalem Agung Pakungwati, Mesjid Agung Sang Cipta Rasa dan Mesjid Astana sebagai lembaga pendidikan Islam utama mengalami kemunduran akibat masuknya intervensi VOC. Pada tahun 1702, VOC memaksa pihak Keraton yang menjadi tiga saat itu untuk menutup Pengguran Dalem Agung sebagai pusat pendidikan Islam. Selain itu, pihak VOC juga secara intensif mengontrol lembagalembaga pendidikan Islam lainnya terutama Mesji Agung Sang Cipta Rasa dan Mesjid Astana selain tempat-tempat lainnya yang dipandang sebagai basis ulama yang dipandang dapat membahayakan kedudukan VOC.

Intervensi VOC mendorong sebagian ulama untuk keluar dari lingkungan Keraton dan membangun institusi pendidikan Islam yang tidak akan bisa diintervensi pihak Kompeni. Pesantren Buntet yang didirikan oleh Kiai Muqoyyim, seorang Mufti Kesultanan Kanoman, pada pertengahan abad ke-18 menjadi cikal bakal lahirnya lembaga pendidikan di luar lingkungan Keraton. Inilah yang oleh 
Muhaimin disebut episode ketiga perkembangan lembaga pendidikan Islam di Cirebon ketika pengelolaan lembaga pendidikan kembali ke masyarakat sebagaimana yang pernah terjadi pada masa awal Islamisasi.

Pada masa selanjutnya, tidak heran jika jaringan intelektual Islam juga membangun channel baru di luar Keraton. Menariknya, sebagaimana pada masa awal Islamisasi Cirebon, jaringan intelektual Islam yang dibangun oleh Kiai dan alumni pesantren adalah jaringan intelektual Islam global dengan menjadikan Mekkah dan Madinah dalam arti yang sebenarnya sebagai rujukan otoritas ilmu keislaman. Para ulama berbasis pesantren ini menghubungkan diri dengan sanad tarekattarekat yang dibawa oleh para alumni atau memiliki jalur silsilah dengan alumni Timur Tengah seperti Syattariyah sebagaimana yang dilakukan oleh Kiai Muqoyyim dan Kiai Anwarudin Kriyan. Sebagian ulama tersebut bahkan pergi langsung ke kota suci kaum Muslim tersebut sebagaimana yang dilaksanakan oleh Kiai Tolkhah yang menyebarkan tarekat qadiriyah wa naqsabandiyah dan Kiai Abbas yang menyebarkan tarekat Tijaniyah. Sejak saat itu dan hingga saat ini, jaringan pesantren mendominasi jaringan intelektual Islam di Cirebon dan sekitarnya.

\section{Kesimpulan}

Cirebon secara historis merupakan salah pusat peradaban Islam di Nusantara.
Berbagai perkembangan yang terjadi baik secara politik, ekonomi, sosial, budaya maupun agama tidak bisa dilepaskan dari berbagai perkembangan yang terjadi di Nusantara. Bahkan, khusus untuk wilayah bagian barat pulau Jawa, Cirebon adalah rujukan utama. Bermula dari Cirebon, politik Islam berkembang hingga melahirkan dua kerajaan Islam terbesar di wilayah bagian barat pulau Jawa sebelum masa kolonialisme yaitu Cirebon dan Banten. Dari tempat ini dan melalui lembaga-lembaga pendidikan Islam yang didirikan berikut para ulama dan alumninya, Islam berikut keilmuannya menyebar ke semua bagian wilayah tersebut. Tentu tidaklah mengagetkan jika Cirebon menjadi rujukan akan Islam dan keilmuannya sekaligus cikal bakal pusat jaringan intelektual Islam di pulau Jawa.

Secara historis, abad ke-16 s.d. 18 merupakan masa peralihan dari episode kedua ke ketiga jaringan intelektual Islam di Cirebon. Masa ini menyaksikan perubahan pusat tradisi keilmuan Islam yang tadinya berpusat di Keraton kemudian berpindah dan menyebar di beberapa wilayah pinggiran di luar keraton seiring dengan munculnya lembaga pendidikan pesantren. Terjadi perpindahan otoritas keagamaan dari Qadi di Keraton ke Kiai di pesantren. Sementara itu dari sisi wacana yang dikembangkan secara umum tidak jauh berbeda dengan wacana yang berkembang di dunia Islam Nusantara secara 
umum yaitu Islam sufistik, meskipun dalam beberapa kasus warna Islam ortodoks yang berorientasi pada fiqh juga cukup berkembang. Hanya saja, pada episode ketiga ini, Islam sufistik semakin berkembang seiring dengan diperkenalkannya tarekat-tarekat ke masyarakat Muslim di Cirebon pada pertengahan abad ke-18 hingga awal abad ke-20.[]

\section{Daftar Pustaka}

Abdurrahman. 1996. "Nawawi al-Bantani: An Intelectual Master of the Pesantren Tradition." Studia Islamika 3 (3).

Atja. 1986. Carita Purwaka Caruban Nagari, Karya Sastra sebagai Sumber Pengetahuan Sejarah. Bandung: Proyek Pengembangan Permesiuman Jawa Barat

Azra, Azyumardi. 1995. "Hadhrami Scholars in the Malay-Indonesian Diapora: A Preliminary Study of Sayyid Uthman," Studia Islamika 2 (2).

-_- 1998. Jaringan Ulama Timur Tengah dan Kepulauan Nusantara Abad XVII dan XVIII. Bandung: Mizan.

—_—. 2002. Jaringan Global dan Lokal: Islam Nusantara. Bandung: Mizan.

. 2006. Islam in the Indonesian World: An Account of Institutional Formation, Bandung: Mizan.

Burhanudin, Jajat. 2007. Islamic Knowledge, Aunthority and Political Power The Ulama in Colonial Indonesia (Ph.D Dissertation). Leiden University. Leiden.
Carey, Peter. 2008. The Power of Prophecy: Prince Dipanagara and the End of an Old Order in Java, 1785-1855. Leiden: KITLV Press.

Cerbon, Pangeran Arya. 1978. Purwaka Tjaruban Nagari (Asal Mula Berdirinya Negara Cirebon) dialih bahasa oleh H.A. Dasuki, Indramayu: t.p.

Danasasmita, Saleh dkk. 1984. Rintisan Penelusuran Masa Silam Sejarah Jawa Barat (Jilid Keempat), Bandung: Proyek Penerbitan Buku Sejarah Jawa Barat Pemerintah Provinsi Daerah Tingkat I Jawa Barat.

Dahuri, Rochmin dkk. 2004. Budaya Bahari sebuah Apresiasi di Cirebon. Jakarta: Perum Percetakan Negara RI.

De Graaf, H.J. dkk, 1998. Cina Muslim di Jawa Abad ke 15 dan 16 Antara Historisitas dan Mitos. Yogyakarta: Tiara Wacana.

Effendi, Khasan. 1994. Petatah-Petitih Sunan Gunung Jati Ditinjau dari Aspek Nilai dan Pendidikan. Bandung: CV Indra Prahasta.

Hadi, Abdul. 2014. Pendidikan di Kota Cirebon 1910-1945, Cirebon: LeKAS.

Hardjasaputra, A. Sobana dan Haris Tawalinudin. 2011. Cirebon: Dalam Lima Zaman (Abad ke-15 hingga Pertengahan Abad ke-20). Bandung: Dinas Pariwisata dan Kebudayaan Provinsi Jawa Barat.

Hoadley, Mason C. 2009. Islam dalam Tradisi Hukum Jawa dan Hukum Kolonial. Yogyakarta: Graha Ilmu.

Irianto, Bambang dan Siti Fatimah. 2009. Syekh Nurjati (Syekh Datul Kahfi): Perintis Dakwah dan Pendidikan, Cirebon: STAIN Press. 
_—_. dan Ki Tarka Sutarahardja. 2013. Sejarah Cirebon: Naskah Keraton Kacirebonan Alih Aksara dan Bahasa Teks KCR 04 (alih aksara dan bahasa). Yogyakarta: Deepublish.

Johns, A.H. 1961. "Sufism as a Category in Indonesian Literature and History." Journal of Southeast Asian History 2 (2).

——_. 1975. "Islam in Southeast Asia: Reflections and New Directions," Indonesia 19, April.

Kertawibawa, Besta Besuki. 2007. Dunasti Raja Petapa I: Pangeran Cakrabuana. Sang Perintus Kerajaan Cirebon. Bandung: PT Kiblat Buku Utama.

Ki Kampah. 2013. Babad Cirebon Carub Kandha Naskah Tangkil, Bambang Irianto dan Ki Tarka Sutarahardja (alih aksara dan bahasa). Yogyakarta: Deepublish.

Masduki, Zaenal. 2011. Cirebon dari Kota Tradisional ke Kota Kolonial, Cirebon: Nurjati Press.

———. dkk. 2012. Islamisasi, Suksesi Kepemimpinan dan Awal Munculnya Kerajaan Islam Cirebon: Kajian dan Penulisan Sejarah Kesultanan Cirebon. Jakarta: Puslitbang Lektur Balitbang Kementrian Agama RI.

Mas'ud, Abdurrahman. 2006. Dari Haramain ke Nusantara: Jejak Intelektual Arsitek Pesantren, Jakarta: Kencana Predana Media Group.

Muhaimin, A. G. 1995. The Islamic Traditions of Cirebon: Ibadat and Adat among Javanese Muslims, Ph.D Thesis, ANU.

___ 1997. "Pesantren and Tarekat in the Modern Era: An Account on the
Transmission of Traditional Islam in Java," Studia Islamika 4 (1).

Nugrahanto, Widyo. 2007. Bertahan di Perantauan. Wacana Cina Muslim di Nusantara Abad ke-15 dan ke-16, Bandung: Uvula Press.

Pigeud, Theodore G. T. H. dan H.J. De Graaf. 1976. Islamic States in Java 1500-1700, The Hague: Nijhof.

Putuhena, M. Sholeh. 2007. Historiografi Haji Indonesia, Yogyakarta: LKiS.

Ricklefs, M. C. 2001. The Histrory of Modern Indonesia since c. 1200, McMillan: Palgarve.

Rochani, Ahmad Hamam. 2008. Babad Cirebon, Cirebon: Dinas Kebudayaan dan Pariwisata Kota Cirebon.

Rido, Rosidi. 2014. Pengguran Sunan Gunung Jati Abad XV-XVI M. (Disertasi). Universitas Islam Negeri Sunan Kalijaga. Yogyakarta.

Rosidin, Didin Nurul. 2013. Syekh Nurjati: Studi atas Islamisasi Pra-Walisongo di Cirebon pada Abad ke-15. Cirebon: Puslit IAIN Syekh Nurjati Cirebon.

——_. dkk. 2013. Kerajaan Cirebon, Jakarta: Puslitbang Lektur dan Khazanah Keagamaan Badan Litbang dan Diklat Kementrian Agama RI.

Safari, Achmad Opan. 2010. Tarekat Kraton Kaprabon: Suatu Kajian Filologis, tesis, Bandung: Universitas Pajajaran.

Shiddique, Sharon J. 1977. The Relics of the Past? Sociological Study of the Sultanates of Cirebon, West Java, (Disertasi Doktor) Universitat of Bielefeld. 
Sulendraningrat, P. S. 1972. Purwaka Tjaruban Nagari, Jakarta: Bhratara.

___. 1984. Babad Tanah Sunda Babad Cirebon, Cirebon: t.p.

Sunardjo, R. H. Unang. 1983. Meninjau Sepintas Pangguran Sejarah Pemerintahan Kerajaan Cirebon 14791809. Bandung: Tarsito.

Syatibi, Ibi. 2013. Nilai-nilai Islam dalam Hukum Adat Papakem (Studi atas Kitab Adilullah Kesultanan Cirebon Abad XVII (Laporan Penelitian) Cirebon: Puslit IAIN Syekh Nurjati.

Tim Peneliti. 1998. Kota Dagang Cirebon sebagai Bandar Jalur Sutra, Jakarta: Departemen Pendididikan dan Kebudayaan RI.

Tjandrasasmita, Uka. 2005. "Kedatangan dan Penyebaran Islam." Eksiklopedi Tematis Dunia Islam. Jilid 5 Asia Tenggara. Jakarta: PT Ichtiar Baru van Hoeve. van Bruinessen, Martin. 1994. "The Origins and Development of Sufi Orders (Tarekat) in Southeast Asia." Studia Islamika 1 (1).

___. 1995. "Shari'a Court, Tarekat amd Pesantren: Religious Institutions in the Banten Sultanate," Archipel 50. Paris.

Wahyu, Amman N. 2005. Sejarah Wali Syekh Syarif Hidayatullah Sunan Gunung Jati (Naskah Mertasinga). Cet. 1, Bandung: Pustaka.

-_—. 2005. Sejarah Wali, Syarif Hidayatullah, Sunan Gunung Jati (Naskah Kuningan) Cet. 1. Bandung: Penerbit Pustaka.

Wildan, Dadan. 2012. Sunan Gunung Jati: Petuah, Pengaruh dan Jejak-jejak Sang Wali di Tanah Sunda. Ciputat: Salima.

Zuhdi, Susanto ed. 1996. Cirebon sebagai Bandar Jalur Sutra. Jakarta: Departemen Pendidikan dan Kebudayaan RI. 


\section{Author Guidelines}

\section{A. Persyaratan Umum}

1. Naskah merupakan hasil penelitian sosial keagamaan dan modernitas yang sudah diformat sesuai pola penulisan artikel jurnal ilmiah.

2. Naskah diutamakan ditulis dalam Bahasa Inggris.

3. Naskah merupakan karya orisinil (bukan plagiasi) dan belum pernah dimuat di jurnal atau media cetak/online lainnya.

4. Naskah dikirim ke Redaksi JSW: Jurnal Sosiologi Walisongo melalui submission Open Journal Systems (OJS) pada http://journal.walisongo.ac.id/index.php/jsw

5. Naskah diketik menggunakan Microsoft Word format RTF, font Times New Roman, size 12 pt, 1,5 spasi, ukuran halaman A4, dengan panjang tulisan 20-25 halaman (sekitar 5.000 - 7.000 kata).

6. Untuk menperoleh keterangan lebih lanjut, silakan menghubungi redaksi melalui email: jurnal.sosiologi@walisongo.ac.idatau menghubungi kantor redaksi (024) 76435986.

\section{B. Persyaratan Khusus}

1. Naskah merupakan hasil penelitian dalam bidang sosial keagamaan dan modernitas.

2. Naskah tidak mencantumkan nama penulis, instansi, dan alamat email. Nama penulis, instansi, dan alamat email dicantumkan saat melakukan registrasi OJS dan pengisian metadata naskah.

3. Naskah memuat:

a. Judul, dengan ketentuan:

- Judul merupakan rumusan pokok bahasan yang singkat, padat, dan jelas.

- Dalam judul sudah tercantum variabel-variabel utama penelitian.

- Judul diketik dengan hurup kapital tebal (capital, bold).

b. Abstrak, dengan ketentuan:

- Abstrak ditulis dalam bahasa Inggris dan bahasa Indonesia. 
- Abstrak merupakan intisari dari pokok bahasan naskah.

- Abstrak ditulis dalam satu paragraf berjarak satu spasi, dengan panjang 100250 kata.

- Abstrak disajikan secara singkat dan jelas, dengan memuat empa. argumentasi logis, perlunya dilakukan penelitian untuk memecahkan masalah, pendekatan yang digunakan (metode), hasil yang dicapai, serta simpulan yang diperoleh (IMRAD: introduction, methods, results, analysis and discussions).

c. Kata Kunci (keywords) maksimal 5 (lima) kata.

d. Isi naskah, dengan sistematika sebagai berikut:

- Pendahuluan yang meliputi latar belakang masalah, perumusan masalah, tujuan dan manfaat penelitian, serta metodologi yang digunakan (IMRAD: introduction, methods, results, analysis and discussions).

- Review pustaka yang berisi kajian teoretik dan hasil penelitian terdahulu yang relevan.

- Hasil dan pembahasan.

- Simpulan dan rekomendasi.

- Daftar pustaka.

4. Rujukan menggunakan ASA (American Sociological Association).[] 


\section{ACKNOWLEDGEMENTS}

The members of the editorial team of JSW: Jurnal Sosiologi Walisongo extend the gratitude to all the reviewers who have contributed to the peer review process of the manuscripts in Vol 1, No 2 (2017). Professional support and assistance from all respected reviewers have made this journal qualified to be published:

1. Abu Rokhmad, Universitas Islam Negeri Walisongo, Semarang

2. Agus Nurhadi, Universitas Islam Negeri Walisongo, Semarang

3. Misbah Zulfa Elizabeth, Universitas Islam Negeri Walisongo, Semarang

4. Muhyar Fananai, Universitas Islam Negeri Walisongo, Semarang

5. Najahan Musyafak, Universitas Islam Negeri Walisongo, Semarang

6. Thohir Yuli Kusmanto, Universitas Islam Negeri Walisongo, Semarang

7. TriMarhaeni Pudji Astuti, Universitas Negeri Semarang 


\section{\begin{tabular}{l|l} 
JW & $\begin{array}{l}\text { JURNAL } \\
\text { SOSIOLOGI } \\
\text { WALISONGO }\end{array}$
\end{tabular}}

JSW: Jurnal Sosiologi Walisongo - ISSN 2503-3166 (print) ISSN 2503-3182 (online) is a critical, reflective, and transformative academic media that is published by Laboratorium Sosiologi, Fakultas IImu Sosial dan IImu Politik, Universitas Islam Negeri Walisongo Semarang, in the effort for developing the discipline of Sociology having the perspective of unity of sciences. Article is based on research in all division of sociology like sociology of religion, sociology of politic, sociology of law, sociology of development, urban/rural sociology, democracy, social ethic, anthropology, community development, social philosophy, gender, and social welfare. 